Jurnal Kebidanan Mutiara Mahakam, Vol 8, No 1, Tahun 2020, Hal 71-76

ISSN : 2623-2553 (Online)

ISSN : 2549-0532 (Cetak)

\title{
HUBUNGAN DUKUNGAN KELUARGA TERHADAP KONSUMSI TABLET TAMBAH DARAH (TTD) DENGAN KEJADIAN ANEMIA PADA REMAJA PUTRI
}

\author{
Arum Estiyani ${ }^{1}$ \\ ${ }^{1}$ Akademi Kebidanan Permata Husada Samarinda \\ email : arumestiyani@gmail.com \\ $\begin{array}{ll}\text { Dikirim } & : \text { 7 Februari } 2020 \\ \text { Diterima } & : \text { 3 Maret 2020 } \\ \text { Diterbitkan } & : \text { 20 Maret } 2020\end{array}$
}

\begin{abstract}
Giving blood added tablets (TTD) to young women for anemia prevention is a government program. This is often inhibited by adherence of young women in consuming TTD. family support is one of the influences in consuming TTD. The purpose of this study was to determine the relationship of family support for TTD consumption with the incidence of anemia in young women. This study used a cross sectional method conducted at SMK N 6 Samarinda with a sample of 30 young women in total sampling. Data collection techniques using questionnaires. Data analysis was performed with the chi square test. The results showed $77 \%$ of young women had high family support and $83 \%$ of young women were not anemic. This study was calculated using SPSS software, obtained a p value of 0.001 , so it can be concluded that there is a Relationship of Family Support Against the Consumption of Blood-Adding Tablets (TTD) with the Occurrence of Anemia in Adolescents. Family support is a factor for adolescent girls to consume blood-added tablets (TTD), the higher the support for adolescent girls' families, the less incidence of anemia.
\end{abstract}

Keyword: Family Support, Blood-Adding Tablets 
Jurnal Kebidanan Mutiara Mahakam, Vol 8, No 1, Tahun 2020, Hal 71-76

\section{PENDAHULUAN}

Remaja putri menjadi golongan yang rawan mengalami anemia karena mereka mudah dipengaruhi oleh lingkungan pergaulan, termasuk dalam pemilihan makanan. Persepsi remaja putri yang salah mengenai bentuk tubuh sehingga membatasi asupan makan, konsumsi makanan sumber protein hewani yang kurang, serta mereka kehilangan zat besi lebih banyak akibat menstruasi di setiap bulannya. Selain itu, strategi penanggulangan anemia pada ibu hamil juga akan lebih efektif jika dilakukan sejak masa remaja (Irianto, 2014).

Anemia banyak terjadi pada masyarakat terutama pada remaja dan ibu hamil. Anemia pada remaja putri sampai saat ini masih cukup tinggi, Jumlah penduduk usia remaja (10-19 tahun) di Indonesia sebesar 26,2\% yang terdiri dari 50,9\% laki-laki dan 49,1\% perempuan (Kemenkes RI, 2013). Kebutuhan besi meningkat pada remaja karena mengalami menstruasi/haid berkala yang mengeluarkan sejumlah zat besi setiap bulan. Peningkatan kebutuhan jumlah total volume darah ini seringkali tidak diikuti dengan konsumsi zat besi yang adekuat, apalagi saat menginjak usia remaja putri cenderung ingin memiliki tubuh yang lebih langsing, sehingga sering melakukan berbagai usaha, di antaranya adalah melakukan diet ketat (Almatsier, 2010).

Menurut Kemenkes RI (2017) persentase remaja putri yang mendapatkan Tablet Tambah Darah (TTD) di Indonesia masih sangat rendah yakni sebesar 10,3\%. Di Kalimantan Timur remaja putri yang mendapat tablet tambah darah menempati urutan pertama terendah mendapat tablet tambah darah dari 32 Provinsi yang ada di Indonesia yakni sebesar 2,86\%. Cakupan pemberian tablet tambah darah pada remaja putri belum memenuhi target nasional yaitu sebesar $30 \%$. Tujuan dari pemberian tablet tambah darah (TTD) pada remaja putri adalah untuk mengurangi anemia.

Penanganan anemia yaitu meningkatkan asupan makanan zat besi, forfikasi makanan dengan zat besi, suplemantasi zat besi. Untuk meningkatkan penyerapan zat besi sebaiknya tablet tambah darah (TTD) dikonsumsi secara bersamaan dengan buah-buahan sumber vitamin $\mathrm{C}$ dan sumber protein hewani seperti hati, ikan, unggas dan daging.

Dari data studi pendahuluan yang dilakukan terdapat 21.513 siswa-siswi SMA yang ada di Samarinda. Menurut Dinas Kesehatan Kota Samarinda prevalensi remaja yang telah mendapatkan tablet tambah darah (TTD) yaitu 791 orang dan siswa-siswi yang beresiko 
Jurnal Kebidanan Mutiara Mahakam, Vol 8, No 1, Tahun 2020, Hal 71-76

terjadi anemia yaitu laki-laki 4.667 orang perempuan 5.101 orang. Data yang dijaring adalah data siswa-siswi yang masih dikelas $X$ atau kelas 1 SMA (DKK Samarinda, 2017). Untuk menanggulangi kejadian anemia yang ada di Indonesia pemerintah mewajibkan remaja putri untuk mengkonsumsi tablet tambah darah (TTD) satu minggu sekali dan apabila menstuasi diwajibkan mengkonsumsi setiap hari.

Salah satu tugas dan peran keluarga adalah untuk menjaga kesehatan anggota keluarganya, terutama pada masa remaja yang merupakan masa pertumbuhan fisik yang pesat (Muhlisin 2012). Berdasarkan studi pendahuluan yang dilakukan di SMK N 6 Samarinda dari 30 remaja putri yang telah diberikan kuisioner terdapat 11 remaja putri yang mengonsumsi tablet tambah darah (TTD) secara teratur dan 19 remaja putri tidak mengonsumsi tablet tambah darah (TTD)

\section{METODE PENELITIAN}

Penelitian ini merupakan jenis penelitian analitik observasional dengan pendekatn cross sectional. Penelitian ini mengambil lokasi di SMKN 6 Samarinda dan dilaksanakan pada 4 april 2019. Populasi pada penelitian ini adalah siswi SMKN 6 Samarinda sebanyak 30 siswi. Dalam penelitian ini cara pengambilan sampel dilakukan dengan menggunakan teknik total sampling.

\section{HASIL DAN PEMBAHASAN}

Penelitian ini dilakukan di SMKN 6 Samarinda dengna jumlah sampel 30 orang.

\section{Distribusi Frekuensi dukungan keluarga}

Distribusi frekuensi umur responden di SMK N 6 Samarinda dapat dilihat didalam tabel dibawah ini:

Berdasarkan penelitian yang dilakukan di SMK N 6 Samarinda terhadap 30 responden didapatkan hasil motivasi sebagai berikut :

Tabel 1 Dukungan keluarga terhadap konsumsi tablet tambah darah (TTD) dengan kejadian anemia pada remaja putri di SMK N 6 Samarinda

\begin{tabular}{lccc}
\hline No & Dulungan Keluarga & Frekuensi (f) & Persentase (\%) \\
\hline 1. & Tinggi & 22 & $77 \%$ \\
\hline 2. & Sedang & 8 & $23 \%$ \\
\hline 3. & Rendah & 0 & $0 \%$ \\
\hline & Jumlah & 30 & $100 \%$ \\
\hline
\end{tabular}


Jurnal Kebidanan Mutiara Mahakam, Vol 8, No 1, Tahun 2020, Hal 71-76

2. Distribusi Frekuensi Kejadian Anemia

Berdasarkan penelitian yang dilakukan di SMK N 6 Samarinda terhadap 30 responden didapatkan hasil kejadian anemia sebagai berikut:

Tabel 2 Kejadian Anemia Pada Remaja Putri

\begin{tabular}{llcc}
\hline No & Kejadian Anemia & Frekuensi (f) & $\begin{array}{c}\text { Persentase } \\
(\%)\end{array}$ \\
\hline 1. & Anemia & 5 & $17 \%$ \\
\hline 2. & Tidak anemia & 25 & $83 \%$ \\
\hline & Jumlah & 30 & $100 \%$ \\
\hline
\end{tabular}

3. Analisa Bivariat

Hubungan motivasi remaja terhadap konsumsi tablet tambah darah (TTD) dengan kejadian anemia pada remaja putri kelas X, XI di SMK N 6 Samarinda

Berdasarkan penelitian yang dilakukan di SMK N 6 Samarinda terhadap 30 responden didapatkan hasil hubungan antara dukungan keluarga remaja terhadap konsumsi tablet tambah darah (TTD) dengan kejadian anemia pada remaja sebagai berikut :

Tabel 3. Hubungan dukungan keluarga terhadap konsumsi tablet tambah darah (TTD) dengan kejadian anemia pada remaja putri kelas X,XI di SMK N 6 Samarinda

\begin{tabular}{|c|c|c|c|c|c|c|c|}
\hline \multirow{3}{*}{$\begin{array}{c}\text { Dukungan } \\
\text { Keluarga }\end{array}$} & \multicolumn{4}{|c|}{ Kejadian Anemia } & \multirow{2}{*}{\multicolumn{2}{|c|}{ Total }} & \multirow{3}{*}{$\mathrm{P}$} \\
\hline & \multicolumn{2}{|c|}{ Anemia } & \multicolumn{2}{|c|}{ Tidak Anemia } & & & \\
\hline & $\sum$ & $\%$ & $\sum$ & $\%$ & $\sum$ & $\%$ & \\
\hline Tinggi & 0 & $0 \%$ & 22 & $100 \%$ & 22 & $100 \%$ & 0,001 \\
\hline Sedang & 3 & $37,5 \%$ & 5 & $62,5 \%$ & 8 & $100 \%$ & \\
\hline Rendah & 0 & $0 \%$ & 0 & $0 \%$ & $0 \%$ & $0 \%$ & \\
\hline Jumlah & 3 & $37,5 \%$ & 27 & $100 \%$ & 30 & $100 \%$ & \\
\hline
\end{tabular}

Tabel 3 menunjukkan bahwa dukungan keluarga tinggi dan tidak mengalami anemia sebanyak 22 orang dan dukungan keluarga tinggi yang anemia tidak ada, dukungan keluarga sedang dengan tidak anemia sebanyak 5 orang dan dukungan keluarga sedang mengalami anemia sebanyak 3 orang. Hasil dari uji chi-square dan hasil uji statistic penelitian ini didapatkan nilai $\mathrm{p}$ value $=0,001<0,05$ yang menunjukkan adanya hubungan yang bermakna antara dukungan keluarga terhadap konsumsi tablet tambah darah (TTD) dengan kejadian anemia pada remaja putri kelas X,XI di SMK N 6 Samarinda sehingga hipotesis diterima. 
Jurnal Kebidanan Mutiara Mahakam, Vol 8, No 1, Tahun 2020, Hal 71-76

Hasil penelitian ini sejalan dengan penelitian yang dilakukan oleh Nur Syaima dkk dengan judul dukungan keluarga dengan nia tablet tambah darah pada remaja putri. Penelitian tersebut menunjukkan bahwa norma subjektif dalam bentuk dukungan keluarga mempengaruhi kuat atau lemahnya perilaku seseorang dalam melakukan suatu tindakan.

Theory of planned behavior oleh Adjen dan Fshbein menyatakan bahwa niat seseorang dipengaruhi oleh tiga factor yaitu sikap terhapa perilaku, norma subjektif, dan persepsi kontrol perilaku. Semakin tinggi dukungan yang diberikan untuk melakukan suatu perilaku maka semakin kuat pula keinginan individu tersebut (Saragih 2014).

Menurut kozier seseorang yang memiliki jaringan pendukung yang adekuat seperti keluarga, teman dekat, atau orang kepercayaan maka akan memiliki kesadaran yang kuat akan resiko terkena penyakit sehingga seseorang akan memelihara kesehatannya. Kozier juga berpendapat bahwa keluarga biasanya akan menurunkan pola perilaku, kebiasaan, dan gaya hidup kepada generasi berikutnya, termasuk dalam mempengaruhi kesehatan anggota keluarganya. Friedman juga berpendapat bahwa fungsi keluarga adalah digunakan untuk mempertahankan keadaan kesehatan anggota keluarganya agar tetap memeliki produktivitas yang tinggi, Oleh karena itu dukungan keluarga pada remaja putri untuk mengkonsumsi Tablet Tambah Darah (TTD) sangat berpengaruh dalam kejadian anemia (Huang, 2015).

\section{SIMPULAN}

1. Remaja putri yang memiliki dukungan keluarga kuat yaitu sebanyak $77 \%$, remaja putri yang memiliki motivasi sedang yaitu sebanyak 33\%, dan yang mempunyai motivasi lemah $0 \%$.

2. Remaja putri yang mengalami anemia di SMK N 6 Samarinda yaitu sebanyak $17 \%$ dan remaja putri yang tidak mengalami anemia yaitu $83 \%$.

3. Hasil uji statistik didapatkan p value 0,001 sehingga dapat disimpulkan bahwa terdapat hubungan antara dukungan keluarga terhadap konsumsi tablet tambah darah (TTD) dengan kejadian anemia pada remaja putri di SMK N 6 Samarinda tahun 2019. 
Jurnal Kebidanan Mutiara Mahakam, Vol 8, No 1, Tahun 2020, Hal 71-76

\section{DAFTAR PUSTAKA}

Almatsier, S. 2009. Prinsip Dasar Ilmu Gizi. PT. Jakarta: Gramedia Pustaka Utama.

Gibney,. J Michael. (2009). Gizi Kesehatan masyarakat. Jakarta

Hurlock. (2011). Psikologi Perkembangan : Suatu Pendekatan Sepanjang Rentang Kehidupan. Jakarta : Erlangga.

Irianto Agus. (2014). Konsep Dasar, Aplikasi dan Pengembangannya. Jakarta : Kencana.

Kementrian Kesehatan Republik Indonesia. (2013). Riset Kesehatan Dasar: Jakarta. Kementrian Kesehatan Republik Indonesia.

Mulyasa, E. (2013). Remaja Rosdakarya. Bandung: Kurikulum Berbasis Komputer.

Proverawati, Asfuah. (2009). Anemia dan Anemia Kehamilan. Yogyakarta : Nuha Medika.

Santrock. (2013). Adolescence. Jakarta : Erlangga.

Sardiman. (2014). Interaksi da Motivasi Belajar Mengajar. Jakrta : Rajawali Press.

Matri, A.K. (2015). Evalusi Program Pemberian Tabletb Tambah Darah sebagai upaya preventif dan kuratif. https://jurnal.ugm.ac.id/bkm/article/view/37448. (download: 28 Februari 2019)

Muhlisin MA. Keperawatan Keluarga. Yogyakarta: Gosyen Publishing; 2012.

Saragih R. Hubungan sikap, norma subjektif, dan perceived behavior control dengan intensi melanjutkan program magister psikologi profesi di Fakultas Psikologi USU. (Skripsi). Medan: Program Studi Psikologi Psikologi Universitas Sumatera Utara: 2014.

Huang CC, Chen TH. Moral norm and the two component theory of planned behavior model in predicting knowledge sharing intention: a role of mediator desire. Sciencetific Research Publishing. 2015; 6: 1686-1689. 